\title{
ДЕТЕРМІНАНТИ УДОСКОНАЛЕННЯ ФУНКЦІОНУВАННЯ СИСТЕМИ ФІНАНСОВОГО ЗАБЕЗПЕЧЕННЯ РОЗВИТКУ ЛІСОВОГО ГОСПОДАРСТВА В УКРАЇНІ
}

\author{
DETERMINANTS OF IMPROVING THE FUNCTIONING OF \\ THE FINANCIAL SUPPORT SYSTEM OF THE FORESTRY \\ DEVELOPMENT IN UKRAINE
}

\author{
Дубина М. В. \\ доктор економічних наук, професор, \\ завідувач кафедри фрінансів, банківської справи та страхування \\ Національний університет «Чернігівська політехніка» \\ ORCID ID: 0000-0002-5305-7815 \\ Зінкевич О. В. \\ здобувач \\ кафедри фрінансів, банківської справи та страхування \\ Національний університет «Чернігівська політехніка» \\ Maksym Dubyna \\ Doctor of Economics, Professor, \\ Head of the Department of Finance, Banking and Insurance \\ Chernihiv Polytechnic National University
}

Oleksandr Zinkevych candidate Department of Finance, Banking and Insurance, Chernihiv Polytechnic National University

Устаттірозглянутопитаннярозвиткугалузілісовогогосподарстватапідвищення рівня фінансовогозабезпечення функціонування лісогосподарських підприємств. Зокрема, розглянуто загальні, економічні та фрінансові заходи для активізації роботи окреслених суб'єктів підприємницької діяльності. Встановлено, що значною мірою розвиток окресленої галузі стримується відсутністю фрінансової незалежності таких суб'єктів, що обумовлюється недостатнім фрінансовим забезпеченнямїх функціонування. Зурахуванням цього устатті виокремлено та описано макросистемні та мікросистемні детермінанти підвищення рівня такого забезпечення. Обгрунтовано, щовпровадженнятакихнапрямівдозволитьзмінити діючузастарілумодельфрінансування галузі лісового господарства, сприятиме впровадженню ринкових механізмів у роботу лісогосподарських підприємств та дозволить сфрормувати основу для впровадження моделісталого лісокористування в Україні. Ключові слова: галузь лісового господарства, лісогосподарське підприємство, лісова політика, національна економіка, фрінансове забезпечення.

В статье рассмотрены вопросы развития отрасли лесного хозяйства и повышение уровня фринансового обеспечения фрункционирования лесохозяйственных предприятий. В частности, рассмотрены общие, экономические и фринансовые меры для активизации работы таких субъектов предпринимательской деятельности. Установлено, что в значительной мере развитие указанной области сдерживается отсутствием фринансовой независимости таких субъектов, обуславливается недостаточным фринансовым обеспечением их функционирования. С учетом этого в статье выделены и описаны макросистемные и микросистемные детерминанты повышения уровня такого обеспечения. Обосновано, что внедрение таких направлений позволит изменить действующую устаревшую модель финансирования отрасли лесного хозяйства, способствовать внедрению рыночных механизмов в работу лесохозяйственных предприятий и позволит сфрормировать основу для внедрения модели устойчивого лесопользования в Украине. Ключевые слова: отрасль лесного хозяйства, лесохозяйственное предприятие, лесная политика, национальная экономика, финансовое обеспечение.

The process of the forestry development in Ukraine requires the search for new tools and measures to intensify the operation of forestry enterprises. The reality is that these businesses are able to provide themselves with financial resources and sustainable development on their own. However, a poor institutional basis for their financing and the lack of funds for the implementation of investment and innovation projects do not allow these companies to increase production, to implement an intensive model of their own activity. The purpose of the article is to identify and sys- 
tematize measures for the development of forestry as a separate sector of the national economy and to increase the level of financial support for the functioning of forestry enterprises. Within the article, the issues of the forestry development and the increase of the level of the forestry enterprises financing are considered. In particular, general, economic and financial measures to intensify the operation of the outlined business entities are considered. It is established that to a large extent the development of the outlined industry is constrained by the lack of financial independence of these entities, which is due to insufficient financial support for their operation. With this in mind, within the article, macro system and microsystem determinants of increasing the level of this support are identified and described. It is quite logical that the implementation of these measures should take place in the framework of a holistic, well-thought-out strategy for the forestry industry development. It is found out in the course of the study that the development and implementation of this strategy should be based on the principles of market economy, the competition of enterprises, their products in open markets of forest products. Thus, gradual implementation of these measures will favor to build in the country and economically friendly space for doing business in the field of forestry. Key words: branch of forestry, forestry enterprise, forestry policy, national economy, financial support.

Постановка проблеми. Розвиток лісового господарства в Україні потребує пошуку нових інструментів та заходів активізації роботи лісогосподарських підприємств. Реальність засвідчує, що ці суб’єкти господарювання цілком самостійно мають змогу забезпечити себе фрінансовими ресурсами та здійснювати стабільний розвиток. Проте неякісна інституційна основа для їх фрінансування та дефріцитність коштів для реалізації інвестиційних та інноваційних проєктів не дозволяють цим підприємствам збільшувати обсяги виробництва, впроваджувати інтенсивну модель власної діяльності. Таким чином, існує потреба у проведенні додаткових досліджень у цьому напрямі $з$ метою пошуку способів вирішення проблем фрінансового забезпечення розвитку цієї галузі, обґрунтування доцільності впровадження відповідних механізмів активізації роботи лісогосподарських підприємств.

Аналіз останніх досліджень і публікацій. Питання розвитку галузі лісового господарства розглядалися в наукових роботах багатьох науковців. До таких учених варто віднести таких: А. Бобко, О. Бойко, І. Дідович, О. Дребот, Т. Єгорова, Х. Замула, М. Іванницька, Р. Леньо, О. Максимець, С. Мельник, В. Непийвода, О. Сакаль, І. Ярошенко. Дослідження особливостей фрінансового забезпечення функціонування лісогосподарських підприємств проводилися такими науковцями: Ю. Голуб, В. Голян, С. Данькевич, О. Дзюбенко, С. Лебедевич, Ю. Марчук, М. Ступень, Б. Шумлянський та ін.

Виділення невирішених раніше частин загальної проблеми, котрим присвячується означена стаття. Однак, незважаючи на наявні наукові результати, які були отримані науковцями, актуальними залишаються питання визначення пріоритетних напрямів розвитку галузі лісового господарства в Україні, пошук нових способів підвищення рівня фрінансового забезпечення роботи лісогосподарських підприємств.

Формулювання цілей статті (постановка завдання). Метою цієї статті $є$ виокремлення та систематизація заходів розвитку лісового господарства як окремої галузі національної економіки та підвищення рівня фрінансового забезпечення функціонування лісогосподарських підприємств.

Виклад основного матеріалу дослідження. Для розгляду основних напрямів розвитку суб'єктів господарювання у галузі лісового господарства та галузі загалом поділимо їх на три основні групи:

1) основні заходи, які спрямовані на загальний розвиток лісогосподарських підприємств і за своєю сутністю не є економічними;

2) економічні заходи, що направлені насамперед на покращення умов для ведення господарської діяльності в цій сфрері;

3) фрінансові заходи - напрями, впровадження яких сприятиме покращенню фінансового забезпечення роботи лісогосподарських підприємств, підвищенню їхньої фрінансової спроможності щодо власного розвитку.

До системних заходів, які варто впроваджувати для створення умов для розвитку галузі лісового господарства, варто віднести такі.

1. Удосконалення законодавчого забезпечення розвитку галузі лісового господарства, урахування міжнародних підходів до організації роботи лісогосподарських підприємств, впровадження принципів сталого лісокористування.

2. Розмежування базових функцій державного регулювання та управління господарською діяльністю в цій сфері, що дозволить підвищити контроль за роботою лісогосподарських підприємств. Для цього необхідно розподілити між окремими регуляторами функції регулювання та контролю за функціонування таких суб'єктів господарювання. Погоджуємося 3 позицією I. В. Ярошенко, що розмежування регуляторних, наглядових і контрольних фрункції державного управління; зміни системи прийняття рішень і підвищення якості державного управління, що дозволить подолати зарегульованість і тиск на бізнес [26, с. 232].

У цьому питанні доцільно використати метод бенчмаркінгу та проаналізувати ссрормовані в розвинутих країнах моделі державного регулювання діяльності лісогосподарських підприємств, враховуючи специфічні риси вітчизняного функ- 
ціонування лісового господарства. Наприклад, переважна більшість питань щодо управління лісовим господарством Канади вирішується на рівні провінцій. На рівні округів основне завдання органів управління лісовим господарством складання середньо- та довгострокових планів використання і відтворення лісів за участю місцевого населення. Управління лісового округу поряд зі складанням планів видає ліцензії на оренду лісових ресурсів з обмеженими правами лісокористувачів. На рівні лісових районів здійснюється основна організаційна робота з лісокористувачами, проводиться контроль за їхньою діяльністю щодо заготівлі деревини, штучного природного поновлення лісів, їх захисту від пожеж та шкідників [19].

3. Сприяння підвищенню ефективності використання інформаційних технологій для впровадження систем протидії незаконним вирубкам лісу, його ефрективному використанню.

4. Сприяння закупівлі сучасних систем переробки лісосічних відходів та відходів деревообробки через придбання пересувних та стаціонарних щепобійних машин. Особливо актуальними окреслені питання стають нині в період активного провадження енергозберігаючих технологій. Відповідно, використання інструментів державної підтримки придбання такого обладнання та техніки дозволить підвищити рівень утилізації неліквідної деревини, порубкових решток, кускових відходів, тирси та стружки, що в результаті дасть можливість значно збільшити обсяги виробництва паливних брикетів та гранул, що зменшить потребу багатьох населених пунктів лісозабезпечних районів у викопних вуглеводнях та сприятиме зменшенню вартості енергоносіїв загалом [5].

5. Активізація фрормування на базі декількох лісогосподарських підприємств розгалужених виробничо-технічних комплексів по збору, сортуванню та переробці недеревних лісових ресурсів з метою диверсифрікації номенклатури виробництва готової продукції, підвищення рівня використання лісоресурсного потенціалу загалом [7].

6. Сприяння розвитку досліджень у цій ссрері, впровадження нових розробок та технологій, залучення у господарську діяльність результатів наукових досліджень, прикладні розроблення, інтелектуальну власність, що дозволить підвищити рівень конкурентоспроможності вітчизняних лісогосподарських підприємств [2, с. 121]. Розвиток науки частково можна реалізувати за рахунок збільшення фрінансування відповідних наукових інститутів, окремих кафедр у 3ВО, які розробляють практично значущих інновації, залучення у господарську діяльність. Це можливо здійснити через відрахування певного відсотка чистого прибутку цих суб'єктів господарювання, що кожний рік перераховується ними до бюджетів різних рівнів.

7. Формування умов для збільшення лісистості території країни до науково обґрунтованого рівня, враховуючи міжнародні критерії віднесення країни до групи самозабезпечувальних лісовими ресурсами держав, що сприятиме зростанню ресурсного й екологічного потенціалу лісів. Також це можливо досягти за рахунок:

- зменшення площі земель, зайнятих чагарниками, рідколіссям, низькомовнотними і нестійкими деревостанами;

- підвищення родючості ґрунтів (меліорація, запобігання ерозії ґрунтів, заболочуванню, засоленню та іншим негативним процесам);

- впровадження сучасних досягнень селекції, лісового насінництва, сортовипробування найцінніших у господарському відношенні деревних порід;

- ефективного догляду за лісовими культурами [8; 21, с. 475].

8. Активізація процесів залучення молоді до роботи в лісогосподарських підприємствах, оскільки на сьогодні спостерігаються проблеми старіння кадрів, небажання молоді працювати в лісогосподарських підприємствах.

Таким чином, впровадження окреслених напрямів дозволить забезпечити поступову трансформацію сформованого інституційного середовища роботи лісогосподарських підприємств і дозволить створити нові умови для їхнього подальшого розвитку. Важливим при цьому $є$ також забезпечення зміни економічних умов, в яких на сьогодні працюють такі суб'єкти господарювання. При цьому важливо реалізувати наступне.

1. Сприяти збільшенню виробництва продукції лісового господарства з високим рівнем доданої вартості, що дозволяє більш раціонально використовувати лісову сировину, збільшувати дохід від її реалізації.

2. Здійснювати пільгове кредитування процесу відтворення лісових насаджень, коли ця діяльність спрямована на створення нових лісів, що мають велике природозахисне і природоохоронне призначення [3; 4, с. $35 ; 10 ; 25]$.

3. Сприяти формуванню ринку лісової сировини, впровадженню сучасних інфрормаційних технологій для біржової торгівлі такою сировиною 3 максимально можливим рівнем транспарентності операцій. Такий підхід дозволить підвищити рівень доходу лісогосподарських підприємств, забезпечити конкуренцію між ними.

4. Активізувати міжнародну співпрацю з іншими органами державного управління та регулювання в галузі лісового господарства, дотримуватися умов укладених договорів щодо реалізації економічної діяльності в цій сфрері, сприяти залученню міжнародних експертів до 
розробки заходів щодо підвищення розвитку лісогосподарських підприємств.

5. Розробити постійну програму підвищення кваліфрікації керівників лісогосподарських підприємств, залучення міжнародних спеціалістів у цій сфрері. Такий підхід дозволить розширити світогляд таких керівників, ознайомити їх із закордонним досвідом роботи подібних підприємств, новими фрормами залучення інвестицій для власного розвитку (фракторинг, франдрайзинг), поглибити управлінські навички роботи.

Отже, впровадження окреслених заходів дозволить стабілізувати роботу лісогосподарських підприємств та створити умови для їх поступового розвитку. Зауважимо, що враховуючи невелику територію лісів, що існують в Україні в порівняні з іншими європейськими країнами, на наше переконання, збільшення ефективності фрункціонування цієї галузі господарства можливе лише через підвищення рівня використання наявних ресурсів. Ліс - це відновлювальний природний ресурс, проте час його відновлення є тривалим, а тому раціональне використання такого ресурсу є запорукою довгострокового розвитку лісового господарства в країні.

Розглянемо тепер більш детально фрінансові заходи щодо активізації роботи лісогосподарських підприємств (рис. 1). Розглянемо деякі 3 представлених заходів більш детально.

Отже, для зміни моделі фрінансування роботи лісогосподарських підприємств, на сьогодні також доцільно:

1. Підвищити контроль за ефективністю витрачання бюджетних коштів, які надають лісогосподарським підприємствам. Найкраще, на наш погляд, це реалізувати шляхом підвищення мотивації керівників таких господарств до якісної роботи. Доцільно впровадити механізми фрінансової самостійності й дозволити таким підприємствам самостійно покривати власні витрати.

Цілком підтримуємо позицію Х. П. Замули, що «доцільно було б перевести лісові господарства на принцип фрінансової самоокупності, щоб вони покривали видатки на свою діяльність за рахунок власних доходів. А, припустимо, лісовідновлювальні роботи могли б фінансуватись із державного бюджету, як це відбувається в Польщі» $[15$, c. 57$]$.

2. Підвищити ефективність використання бюджетних коштів, що виділяються для розвитку лісового господарства, впровадження програмного методу фрінансування окремих державних програм у цій сфрері.

Програмно-цільове фрінансування передбачає визначення об'єктів, чітких цілей фрінансування і необхідних ресурсів, дозволяє уникнути нецільового використання бюджетних коштів, спрямоване на результативне їх витрачання та передбачає персональну відповідальність керівників закладів. Цінність цільового програмного фінансування полягає в тому, що воно дозволяє підходити до вирішення програми комплексно [20].

Таким чином, використання програмно-цільового методу фрінансування розвитку лісогосподарських підприємств дозволить:

1) підвищити ефрективність використання бюджетних коштів;

2) реалізувати чітко необхідні програми підтримки окремих аспектів фрункціонування лісогосподарських підприємств;

3) здійснювати фрінансування окремих заходів у частині збереження лісу, реалізації заходів підвищення протипожежної безпеки;

4) підвищити відповідальність керівників лісогосподарських підприємств за використання бюджетних коштів, які матимуть виключно цільовий характер;

5) забезпечити реалізацію декількох програм, фрінансування яких може відбуватися не за залишковим принципом.

3. Забезпечити вчасне бюджетне фрінансування заходів з відтворення і охорони лісів, локалізації пожеж, локалізації осередків шкідників і захворювання лісу. Зробити такі статті витрат гарантованими та захищеними. Доречно зауважують І. М. Шості, Л. В. Винятинська, що «враховуючи специфріку діяльності лісового господарства, саме виконання різного роду лісовідновлювальних і лісовирощувальних робіт, обслуговування державних об'єктів, виконання державних програм, покладених на них державою тощо, здійснюються за власні кошти. Недостатнє державне фрінансування $€$ головним чинником, що впливає на рівень платоспроможності лісових господарств, оскільки підприємства витрачають кошти на виконання державних робіт, а на погашення термінових зобов'язань коштів не вистачає» $[14$, с. 176$]$.

4. Підвищення інвестиційної привабливості галузі лісового господарства з метою залучення як внутрішніх, так і зовнішніх фрінансових ресурсів. На сьогодні цілком зрозуміло, що держава не може забезпечити належне фінансування роботи лісогосподарських підприємств в Україні. Досвід зарубіжних країн свідчить, що ефективно такі суб'єкти господарювання можуть розвиватися лише в ринкових умовах власного фрункціонування за участі приватного капіталу.

Отже, враховуючи окреслене та особливості функціонування галузі лісового господарства в Україні, для підвищення інвестиційної привабливості цієї галузі необхідно: розробити модель залучення приватних інвестицій до цієї галузі на основі дотримання принципів державно-приватного партнерства, колективного співробітництва 

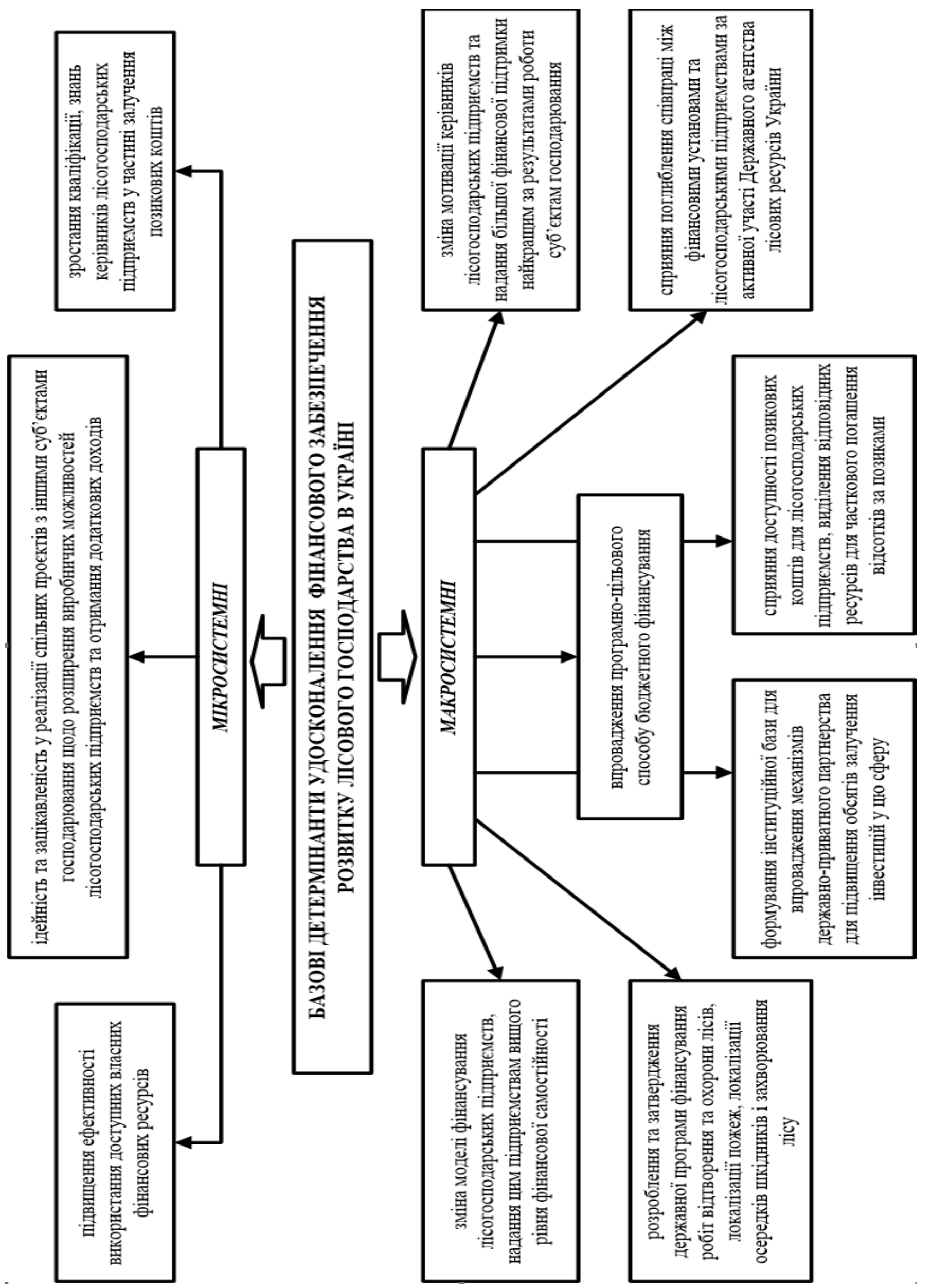

Рис. 1. Базові детермінанти удосконалення фінансового забезпечення розвитку лісового господарства в Україні

Джерело: систематизовано та доповнено автором на основі [6; 12; 13; 16; 17; 18; 22, с. 33; 27; 28] 
та управління лісогосподарськими підприємствами, що повинно базуватися на забезпеченні, з одного боку, інтересів держави, яка представляю інтереси українського суспільства, а 3 іншого - на забезпеченні можливостей отримувати дохід приватними інвесторами; необхідно сприяти поглибленню опрацювання деревини, створенню кластерів у цій галузі, до складу яких повинні входити як підприємства із заготівлі лісової сировини, так і підприємства з її обробки, виготовлення вже лісових товарів та продукції [24].

5. Створення загальнодержавного Фонду розвитку лісового господарства, формування фінансових ресурсів якого можливо здійснювати за рахунок відрахування від рентної плати за використання лісових ресурсів та через передачу частину чистого прибутку лісогосподарських товариств, які вони отримують [1]. Необхідність створення такого Фонду пояснюється наявністю потреби в реалізації складних національних заходів щодо підтримки лісового господарства, реформування окремих його складових. Також кошти цього Фонду можуть використовуватися для відновлення лісу в результаті настання стихійних лих, техногенних аварій. Частково кошти Фонду доцільно витрачати на розвиток мисливського господарства, розведення диких тварин, підтримку їхньої життєдіяльності.

Важливою умовою розвитку лісового господарства $є$ рух по траєкторії впровадження принципів сталого лісокористування. Звичайно, лісова галузь України на сьогодні перебуває не в тому економічному та фінансовому стані, за якого досить просто впроваджувати методи та інструменти побудови моделі сталого лісокористування. Наріжними принципами всього лісового законодавства ЄС є сталий лісовий менеджмент та багатофункціональна роль лісів. Співтовариство розуміє, що забезпечення сталого лісового менеджменту веде до росту 87 операційних витрат і, як наслідок, - до зниження конкурентоспроможності лісового сектору [11, с. 86-87].

Однак окремі аспекти її можливо впроваджу- вати вже сьогодні, формуючи умови для гармонійного розвитку економічних, соціальних та екологічних систем.

Також у контексті функціонування лісогосподарської галузі на основі впровадження моделі сталого розвитку , варто впроваджувати такі заходи для підвищення якості діяльності лісогосподарських підприємств [9; 23]:

1) сприяти поглибленню співпраці між цими підприємствами та територіальними громадами, які існують на території, що знаходиться поблизу лісових масивів (об'єктами сільського туризму);

2) підвищувати рівень лісогосподарського менеджменту;

3) диверсифікувати лісогосподарським підприємствам власні надходження від побудови туристичних маршрутів для екологічного туризмy;

4) будувати об'єкти лісової інфраструктури поодаль від екологічно чистих місць та територій проживання диких тварин;

5) налагодження співпраці із сільськогосподарськими підприємствами, унеможливлення використання хімічних добрив, що негативно впливають на розвиток лісових масивів і т. ін.

Висновки. Отже, у статті проаналізовано та запропоновано систему базових детермінант розвитку лісового господарства та підвищення рівня фрінансового забезпечення функціонування лісогосподарських підприємств в Україні. Цілком логічним $€$ те, що впровадження таких заходів повинно відбуватися в межах реалізації цілісної, продуманої стратегії розвитку лісової галузі. Проте в результаті дослідження встановлено, що в основу розробки та реалізації такої стратегії повинні бути покладені принципи функціонування ринкової економіки, конкуренції підприємств, їх товарів на відкритих ринках лісової продукції. Таким чином, поступове впровадження наведених заходів дозволить побудувати в країні економічно сприятливий простір для ведення підприємницької діяльності в галузі лісового господарства.

\section{БІБЛІОГРАФІЧНИЙ СПИСОК:}

1. Бобко А. Лісівництво і державна політика щодо користування землями лісогосподарського призначення в Україні. Економіка України. 2012. № 7. С. 70-79.

2. Бойко О. В., Іваницька М. Я. Механізм формування стратегії інноваційного розвитку лісогосподарських підприємств. Маркетинг і менеджмент інновацій. 2011. № 2. С. 119-123.

3. Голуб Ю. О. Кредитна складова фінансового забезпечення діяльності суб'єктів господа-рювання : автореф. дис. ... канд. екон. наук: 08.00.08 / Харківський національний економічний університет. Харків, 2011. 20 с.

4. Голян В. А., Голуб О. А. Фінансове забезпечення пріоритетів розвитку лісогосподарського комплексу: диверсифікація форм і засобів. Проблеми економіки. 2016. № 3. С. 31-39.

5. Голян В. А., Петруха С. В., Рошкевич В. Ф. Державне регулювання інституціональних змін у лісовому секторі економіки України: теоретико-методологічний контекст. Економіка та держава. 2018. № 11. С. 8-14. https://doi.org/10.32702/2306-6806.2018.11.8

6. Дзюбенко О. М. Залучення зовнішніх інвестицій у сферу господарського освоєння ліс ресурсного потенціалу та деревообробну галузь: інституціональні та територіальні передумови. Проблеми економіки. 2017. № 4. C. $437-443$. 
7. Дзюбенко О. М. Інвестиційно-інноваційне забезпечення лісогосподарських заходів постійних лісокористувачів в умовах поглиблення інституціональних перетворень. Проблеми економіки. 2017. № 3. С. 283-291.

8. Дідович І. І., Кульчицька Е. А. Загальні засади організації виготовлення органічної не деревної продукції як складової стратегії реформування лісового господарства України на період до 2022 року. Науковий вісник НЛТУ України. 2019. Т. 29, № 4. С. 11-15. https://doi.org/10.15421/40290402

9. Дребот О. І., Шершун М. Х., Шкуратов О. І. Збалансований розвиток лісового сектору економіки контексті європейської інтеграції України: монографія / за наук. ред. Акад. НААН О. І. Фурдичка. Київ : Аграр. наука. 2014. 348 c.

10. Дубина М. В., Зінкевич О. В. Теоретичні аспекти функціонування та розвитку лісового господарства в Україні. Бізнес Інформ. 2020. № 2. С. 187-192. https://doi.org/10.32983/2222-4459-2020-2-187-192

11. Єгорова Т. П. Європейське лісове законодавство як інноваційний елемент удосконалення національної лісової політики. Адаптація до права ЄС регулювання економіки України в сучасних умовах : зб. наук. пр. (за матеріалами «Круглого столу», м. Харків, 26 трав. 2015 р.). Харків, 2015. С. 86-94.

12. Жаворонок А. Комплексне оцінювання фінансового стану підприємств лісогосподарської галузі як передумова залучення фінансових ресурсів. Галицький економічний вісник. 2020. Том 65. № 4. C. 138-150. https:// doi.org/10.33108/galicianvisnyk_tntu2020.04.138

13. Жаворонок А. В., Ковальчук Н. О. Особливості фрінансового забезпечення вітчизняних підприємств лісового господарства. Інфраструктура ринку. 2020. № 43. С. 154-159. DOI: https://doi.org/10.32843/infrastruct43-28.

14. Заверюха М. Правове регулювання загального використання лісових ресурсів в Україні та зарубіжних країнах. Підприємництво, господарство і право. 2017. № 6. С. 96-99.

15. Замула Х. П. Сучасний стан ведення лісового господарства в Україні. Агросвіт. 2013. № 19. С. 54-59.

16. Кичко І. І., Гарус Ю. О. Перспективи розвитку лісового господарства України. Глобальні та національні проблеми економіки. 2016. Вип. 1. С. 128-132.

17. Косач I. Концептуальні засади розробки стратегії розвитку державно-приватного партнерства в АПК України. Проблеми і перспективи економіки та управління. 2018. № 1 (13). C. 24-31. https://doi.org/10.25140/24115215-2018-1(13)-24-31

18. Лебедевич С. І., Говда Г. А. Основні засади аудит екологічних витрат підприємств лісового господарства. Науковий вісник НЛтУ України. Серія економічна. 2017. Вип. 27. № 2. С. 17-19.

19. Леньо Р. В. Перспективні напрями впровадження зарубіжного досвіду в систему управління лісовим господарством України. Державне управління: теорія та практика. 2012. № 2. URL: http://nbuv.gov.ua/j-pdf/ Dutp_2012_2_21.pdf.

20. Лободіна 3. М. Форми та методи фінансового забезпечення закладів охорони здоров'я дітей. URL: http:// www.rusnauka.com/2._SND_2007/Economics/19165.doc.htm.

21. Макаренко С. С. Оцінка діяльності лісового господарства України у контексті вимог часу. Економіка та суспільство. 2018. Вип. 19. С. 472-478. https://doi.org/10.32782/2524-0072/2018-19-72

22. Марчук Ю. М. Фінансове забезпечення ведення лісового господарства: диверсифікація пріоритетів та джерел. Інвестиції: практика та досвід. 2019. № 23. С. 29-34. https://doi.org/10.32702/2306-6814.2019.23.29

23. Мельник С. О. Еколого-економічні аспекти реформування лісового господарства України : автореф. дис. ... к.е.н. : 08.08.01 "Економічна теорія та історія економічної думки" / Український держ. лісотехнічний ун-т. Львів, 2003. 20 с.

24. Ступень М. Г., Шумлянський Б. В. Сучасні механізми реалізації інвестиційних проектів у лісовому секторі. Збалансоване природокористування. 2015. №2. С. 5-9.

25. Холявко Н. І. Сучасні інформаційні технології в роботі фінансових установ. Бізнес Інформ. 2021. № 5. C. 152-161. https://doi.org/10.32983/2222-4459-2021-5-152-161

26. Ярошенко І. В. Формування лісової політики України. Бізнес Інфрорм. 2018. № 5. С. 229-233.

27. Popelo O. Analysis of resource potential of Ukraine regions. Проблеми і перспективи економіки та управління. 2018. № 2 (14). C. 64-83. https://doi.org/10.25140/2411-5215-2018-2(14)-64-83

28. Popelo O. Analysis of the level of ecological sphere modernization as a component of the productive forces modernization of the Ukraine regions. Проблеми і перспективи економіки та управління. 2018. № 1 (13). С. 98104. https://doi.org/10.25140/2411-5215-2018-1(13)-98-104

\section{REFERENCES:}

1. Bobko, A. (2012). Lisivnytstvo i derzhavna polityka shchodo korystuvannia zemliamy lisohospodarskoho pryznachennia $v$ Ukraini [Forestry and state policy on the use of forest lands in Ukraine]. Ekonomika Ukrainy Economy of Ukraine, (7), 70-79. (in Ukrinian).

2. Boiko, O. V., Ivanytska, M. Ya. (2011). Mekhanizm formuvannia stratehii innovatsiinoho rozvytku lisohospodarskykh pidpryiemstv [Mechanism of forming of strategy of innovative development of forestry enterprises]. Marketynh i menedzhment innovatsii - Marketing and innovation management, (2), 119-123. (in Ukrinian).

3. Holub, Yu. O. (2011). Kredytna skladova finansovoho zabezpechennia diialnosti subiektiv hospoda-riuvannia [Credit component of financial support of economic entities] [PhD dissertation, Kharkivskyi natsionalnyi ekonomichnyi universytet]. (in Ukrinian).

4. Holian, V. A., Holub, O. A. (2016). Finansove zabezpechennia priorytetiv rozvytku lisohospodarskoho kompleksu: dyversyfikatsiia form i zasobiv [Financial support of the forestry complex development priorities: diversification of 
forms and means]. Problemy ekonomiky - Problems of the economy, (3), 31-39. (in Ukrinian).

5. Holian, V. A., Petrukha, S. V., Roshkevych, V. F. (2018). Derzhavne rehuliuvannia instytutsionalnykh zmin u lisovomu sektori ekonomiky Ukrainy: teoretyko-metodolohichnyi kontekst [State regulation of institutional changes in the forest sector of ukraine: theoretical and methodological context]. Ekonomika ta derzhava - Economy and state, (11), 8-14. https://doi.org/10.32702/2306-6806.2018.11.8 (in Ukrinian).

6. Dziubenko, O. M. (2017). Zaluchennia zovnishnikh investytsii u sferu hospodarskoho osvoiennia lis resursnoho potentsialu ta derevoobrobnu haluz: instytutsionalni ta terytorialni peredumovy [Attracting foreign investment in the field of economic development of forest resource potential and woodworking industry: institutional and territorial prerequisites]. Problemy ekonomiky - Problems of the economy, (4), 437-443. (in Ukrinian).

7. Dziubenko, O. M. (2017). Investytsiino-innovatsiine zabezpechennia lisohospodarskykh zakhodiv postiinykh lisokorystuvachiv $\vee$ umovakh pohlyblennia instytutsionalnykh peretvoren [Investment and innovation support of forestry activities of permanent forest users in the deepening of institutional transformations]. Problemy ekonomiky Problems of the economy, (3), 283-291. (in Ukrinian).

8. Didovych, I. I., Kulchytska, E. A. (2019). Zahalni zasady orhanizatsii vyhotovlennia orhanichnoi ne derevnoi produktsii yak skladovoi stratehii reformuvannia lisovoho hospodarstva Ukrainy na period do 2022 roku [General principles of organization of manufacture of organic non-wood production as a component of the strategy of reformation of Ukrainian forestry for the period up to the year 2022]. Naukovyi visnyk NLTU Ukrainy - Bulletin of NLTU of Ukraine, 29(4), 11-15. https://doi.org/10.15421/40290402 (in Ukrinian).

9. Drebot, O. I., Shershun, M. Kh., Shkuratov, O. I., Furdychek O. I. (Ed.). (2014). Zbalansovanyi rozvytok lisovoho sektoru ekonomiky konteksti yevropeiskoi intehratsii Ukrainy [Balanced development of the forest sector of economy in the context of the European integration of Ukraine]. Ahrar. nauka. (in Ukrinian).

10. Dubyna, M. V., Zinkevych, O. V. (2020). Teoretychni aspekty funktsionuvannia ta rozvytku lisovoho hospodarstva v Ukraini [The theoretical aspects of the functioning and development of forestry in Ukraine]. Biznes Inform - Business Inform, (2), 187-192. https://doi.org/10.32983/2222-4459-2020-2-187-192 (in Ukrinian).

11. Yehorova, T. P. (2015). Yevropeiske lisove zakonodavstvo yak innovatsiinyi element udoskonalennia natsionalnoi lisovoi polityky [European forest legislation as an innovative element of improving the national forest policy]. Proceeding Adaptatsiia do prava YeS rehuliuvannia ekonomiky Ukrainy v suchasnykh umovakh: zb. nauk. pr. - Adaptation to the EU law regulating economy of Ukraine in modern conditions: Collection of research papers (pp. 86-94). (in Ukrinian).

12. Zhavoronok, A. (2020). Kompleksne otsiniuvannia finansovoho stanu pidpryiemstv lisohospodarskoi haluzi yak peredumova zaluchennia finansovykh resursiv [Comprehensive assessment of the financial status of forestry enterprises as a prerequisite for financial resources attraction]. Halytskyi ekonomichnyi visnyk - Galician economic journal, 65(4), 138-150. https://doi.org/10.33108/galicianvisnyk_tntu2020.04.138 (in Ukrinian).

13. Zhavoronok, A. V., Kovalchuk, N. O. (2020). Osoblyvosti finansovoho zabezpechennia vitchyznianykh pidpryiemstv lisovoho hospodarstva [Peculiarities of financial support of domestic forestry enterprises]. Infrastruktura rynku - Market infrastructure, (43), 154-159. (in Ukrinian). URL: https://doi.org/10.32843/infrastruct43-28.

14. Zaveriukha, M. (2017). Pravove rehuliuvannia zahalnoho vykorystannia lisovykh resursiv $v$ Ukraini ta zarubizhnykh krainakh [Legal regulation of general use of forest resources in Ukraine and foreign countries]. Pidpryiemnytstvo, hospodarstvo i pravo - Entrepreneurship, economy and law, (6), 96-99. (in Ukrinian).

15. Zamula, Kh. P. (2013). Suchasnyi stan vedennia lisovoho hospodarstva v Ukraini [Current status of forestry in Ukraine]. Ahrosvit - Agroworld. (19), 54-59. (in Ukrinian).

16. Kychko, I. I., Harus, Yu. O. (2016). Perspektyvy rozvytku lisovoho hospodarstva Ukrainy [Prospects of development of forestry of Ukraine]. Hlobalni ta natsionalni problemy ekonomiky - Global and National Problems of Economy, 1, 128-132. (in Ukrinian).

17. Kosach, I. (2018). Kontseptualni zasady rozrobky stratehii rozvytku derzhavno-pryvatnoho partnerstva v APK Ukrainy [Conceptual basics for the formation of the strategy of public-private partnership development in Ukrainian $\mathrm{AIC}$. Problemy i perspektyvy ekonomiky ta upravlinnia - Problems and prospects of economics and management, (1(13)), 24-31. https://doi.org/10.25140/2411-5215-2018-1(13)-24-31 (in Ukrinian).

18. Lebedevych, S. I., Hovda, H. A. (2017). Osnovni zasady audyt ekolohichnykh vytrat pidpryiemstv lisovoho hospodarstva [Basic principles of environmental costs auditing of forestry enterprises]. Naukovyi visnyk NLTU Ukrainy. Seriia ekonomichna - Scientific Bulletin of UNFU. Economic Series, 27(2), 17-19. (in Ukrinian).

19. Leno, R. V. (2012). Perspektyvni napriamy vprovadzhennia zarubizhnoho dosvidu v systemu upravlinnia lisovym hospodarstvom Ukrainy [The perspective directions of the implementation of the foreign experience in the system of governance of the forest management in Ukraine]. Derzhavne upravlinnia: teoriia ta praktyka - Public administration: theory and practice, (2). (in Ukrinian). URL: http://nbuv.gov.ua/j-pdf/Dutp_2012_2_21.pdf.

20. Lobodina, Z. M. (2007). Formy ta metody finansovoho zabezpechennia zakladiv okhorony zdorovia ditei [Forms and methods of financial support of children's health care institutions]. (in Ukrinian). URL: http://www. rusnauka.com/2._SND_2007/Economics/19165.doc.htm.

21. Makarenko, S. S. (2018). Otsinka diialnosti lisovoho hospodarstva Ukrainy u konteksti vymoh chasu [Assessment of forestry activity of Ukraine in the context of time requirements]. Ekonomika ta suspilstvo - Economy and society. 19, 472-478. https://doi.org/10.32782/2524-0072/2018-19-72 (in Ukrinian).

22. Marchuk, Yu. M. (2019). Finansove zabezpechennia vedennia lisovoho hospodarstva: dyversyfikatsiia priorytetiv ta dzherel [Financial support for forest management: diversification of priorities and sources]. Investytsii: praktyka 
ta dosvid - Investments: practice and experience, (23), 29-34. https://doi.org/10.32702/2306-6814.2019.23.29 (in Ukrinian).

23. Melnyk, S. O. (2003). Ekoloho-ekonomichni aspekty reformuvannia lisovoho hospodarstva Ukrainy [Ecological and economic aspects of the forestry reform in Ukraine] [PhD dissertation, Ukrainskyi derzh. lisotekhnichnyi un-t].

24. Stupen, M. H., Shumlianskyi, B. V. (2015). Suchasni mekhanizmy realizatsii investytsiinykh proektiv u lisovomu sektori [Modern mechanisms for implementing investment projects in the forest sector]. Zbalansovane pryrodokorystuvannia - Balanced nature management, (2), 5-9.

25. Kholiavko, N. I. (2021). Suchasni informatsiini tekhnolohii v roboti finansovykh ustanov [Modern information technologies in the activities of financial institutions]. Biznes Inform - Business Inform, (5), 152-161. https://doi. org/10.32983/2222-4459-2021-5-152-161 (in Ukrinian).

26. Yaroshenko, I. V. (2018). Formuvannia lisovoi polityky Ukrainy [Formation of forest policy of Ukraine]. Biznes Inform - Business Inform, (5), 229-233 (in Ukrinian).

27. Popelo, O. (2018). Analysis of resource potential of Ukraine regions. Problems and prospects of economics and management, (2(14)), 64-83. https://doi.org/10.25140/2411-5215-2018-2(14)-64-83

28. Popelo, O. (2018). Analysis of the level of ecological sphere modernization as a component of the productive forces modernization of the Ukraine regions. Problems and prospects of economics and management, (1(13)), 98104. https://doi.org/10.25140/2411-5215-2018-1(13)-98-104 